\title{
Carp coccidiosis: intestinal histo- and cytopathology under Goussia carpelli infection
}

\author{
Simone Jendrysek ${ }^{1}$, Dieter Steinhagen ${ }^{1}$, Wolfgang Drommer ${ }^{2}$, Wolfgang Körting ${ }^{1}$ \\ 'Fish Disease Research Unit and 2 Pathology Department, School of Veterinary Medicine, Bünteweg 17, D-30559 Hannover, \\ Germany
}

\begin{abstract}
The tissue response of carp Cyprinus carpio to the coccidian parasite Goussia carpelli (Leger \& Stankovitch, 1921) was investigated during a laboratory infection by histological and electron microscopical techniques. During merogonic and early gamogonic development severe damage to infected epithelial tissue was observed, resulting in extensive loss of epithelium and damage to the lamina propria. In heavily infected carp, the most severe damage was observed in late merogony and early gamogony at about Day 9 post exposure, when the epithelium was destroyed with the exception of some remnants deep between mucosa folds. As a repair mechanism of destroyed tissue, areas of naked propria became covered by broad, plain cells of a squamous epithelium within a few days. Enterocytes harbouring $G$. carpelli oocysts were observed to migrate into subepithelial tissue. Phagocytic activity was seen in all granulocyte types in the gut. Compared to coccidia of birds and mammals, the tissue damage caused by $G$. carpelli indicated high pathogenic capacity. The weak clinical symptoms of this coccidiosis might be explained by the rapid repair of destroyed tissue and the absence of dehydration in freshwater fishes.
\end{abstract}

KEY WORDS: Carp coccidiosis - Goussia carpelli Histopathology

\section{INTRODUCTION}

Goussia carpelli Léger \& Stankovitch (1921) is the causative agent of the enteritis coccidiosis, which is regarded as a serious disease in hatchery populations of young carp from Europe and North America (Schäperclaus 1979, Reichenbach-Klinke 1980, Amlacher 1981). The pathogenicity of G. carpelli has remained unclear: carp breeders and fish pathologists report growth depression and occasional heavy losses associated with enteritis coccidiosis. Doflein \& Reichenow (1953) described high mortalities in carp fry caused by a $G$. carpelli infection and, according to Kocylowski et al. (1976), G. carpelli is highly pathogenic and causes enteritis, intestine atrophy and emaciation associated with a high mortality rate. Affected fish populations, however, often have to face additional stressors at the same time, e.g. further infections with parasitic, bacterial, or viral pathogens or handling stressors, which make it difficult to assign unambiguous responsibility for the mortalities observed to a $G$. carpelli infection.

The information on the histopathology of this coccidiosis available from the literature is also contra- dictory. Lom \& Dyková (1992) described dystrophy, necrosis, desquamation of infected enterocytes, and a diffuse enteritis associated with lymphocytic infiltration of subepithelial connective tissue and the muscularis in Goussia carpelli infected carp. In 30 to $45 \mathrm{~d}$ old goldfish, Kent \& Hedrick (1985) found chronic enteritis, a destruction of the villar structure and infiltration by mononuclear cells. In the intestines of the fishes examined, Alvarez-Pellitero \& Gonzalez-Lanza (1985) found $G$. carpelli oocysts but no noteworthy histopathological changes.

To estimate the pathogenicity of Goussia carpelli, the effect of different developmental stages on the host tissue has to be examined. For this purpose, histopathological studies on intestinal tissue of laboratory infected carp during a complete developmental cycle of the parasite were performed. In contrast to former investigations, which described the histopathological effects of piscine coccidia from hosts with spontaneous infections, in this study we present data on the histopathology of intestinal coccidia of carp derived from a laboratory infection. This enabled us for the first time to examine the effects of consecutive developmental stages of the parasite on the intestinal tissue. 


\section{MATERIALS AND METHODS}

One day old carp larvae Cyprinus carpio were obtained from the Bundesforschungsanstalt für Fischerei Ahrensburg (Germany) and raised in our laboratory under coccidia-free conditions. For a laboratory infection, 38 carp ( 9 mo old, 4 to $8 \mathrm{~cm}$ body length) were exposed to coccidia in a tank contaminated with $G$. carpelli oocysts for $30 \mathrm{~h}$. Then the fish were transferred to a coccidia-free tank and kept at $20^{\circ} \mathrm{C}$. During the experiment, the fish were not fed. As controls, uninfected carp from the same stock were kept under similar conditions. At Days 4 and 6 post exposure (PE), 2 fish from each group were sampled, at Days 7 to 12 PE, 3 fish each day and at Days 13 to $15,17,19,22,26$ and 31 PE, 2 fish each were sampled. Samples for light microscopy and electron microscopy were taken from the same fish at various locations of the gut. Fish to be sampled were chilled on ice, killed, and necropsied, and the intestine was removed quickly and placed into ice-cold fixative $[4 \%(\mathrm{w} / \mathrm{v})$ paraformaldehyde in phosphate buffer, pH 7.2; $0.067 \mathrm{M}$. For further examination, tissue samples from the entire small intestine were taken and processed as follows:

For light microscopy (LM), 3 to $4 \mathrm{~mm}$ pieces of the intestine were fixed in phosphate buffered formaldehyde for $24 \mathrm{~h}$, washed in the same buffer, dehydrated in an ascending series of ethanol and embedded in glycol-methacrylate (Technovit 7100, Kulzer, Wehrheim, Germany). Sections were cut at $3 \mu \mathrm{m}$, stained with haematoxylin-eosin, periodic acid Schiff or Giemsa; microphotographs were taken with a Zeiss Axiophot photomicroscope on Kodak technical Pan film.

For transmission electron microscopy (TEM), 2 to $3 \mathrm{~mm}$ pieces of intestinal tissue were fixed in ice-cold $5 \%$ glutaraldehyde in $0.1 \mathrm{M}$ cacodylate buffer for $24 \mathrm{~h}$, washed, and postfixed in $1 \%$ osmium tetroxide in the same buffer for $1 \mathrm{~h}$. After dehydration and embedding in Epon 812, $70 \mathrm{~nm}$ thin sections were cut, stained with uranyl acetate and lead citrate and observed in a Zeiss EM $10 \mathrm{C}$ electron microscope.

\section{RESULTS}

The histology of the intestine from uninfected control carp is depicted in Fig. 1: slender mucosal folds, covered by an epithelium of columnar enterocytes extend into the gut lumen. The submucosal tissue of the lamina propria and the submucosa consists of a layer of connective tissue with irregularly dispersed leucocytes and phagocytes.

Intracellular stages of Goussia carpelli were first observed at Day 4 PE: single elongated trophozoites and meronts, located in epinuclear sites in the entero- cytes, apico-basally oriented and adapted to the form of the host cell (Fig. 2). Light and electron microscopical observations did not reveal any reaction of the infected enterocytes at this time. The brush border zone of the enterocyte lining was regular and continuous, and the cell organelles were unchanged in number, structure and distribution (Fig. 2).

Due to a rapid increase of parasite numbers during the subsequent phase of merogony, the infection of enterocytes intensified rapidly and spread from the tips of the mucosal folds towards more basal regions, until nearly all enterocytes harboured at least 1 parasite (Fig. 4). Up to 8 coccidian stages were found in a single cell. Initially the parasites were located in the epinuclear region of the host cell (Fig. 3). In this cell region, they caused a dislocation and deformation of organelles and an increase of cell size, which was visible as a protrusion of the apical plasma membrane. The infranuclear part of the host cell remained unchanged (Fig. 3). With increasing number and diameter of invaded stages, the entire cell was occupied by the parasites. This occurred 6 to $9 \mathrm{~d} \mathrm{PE}$ and coincided with clear signs of degeneration of apical regions of affected enterocytes: a slight, later distinct protrusion of the apical plasma membrane was accompanied by shortening and finally complete loss of microvilli. The apical membrane then budded off blebs or digital protrusions (see Fig. 7).

Numerous signs of cell degeneration were visible in the enterocytes: a cell oedema was formed; the endoplasmic reticulum (ER) and the perinuclear cisternae dilated and formed large cisternae, which often fragmented into isolated vesicles. The mitochondria were swollen, lost the regular structure of the cristae, and finally the mitochondrial membranes ruptured and inclusions of coagulated matter were formed.

At Day $8 \mathrm{PE}$, desquamation of enterocytes was observed at the tips of the mucosa folds (Fig. 5). These cell losses were caused by a necrotizing of enterocytes, which deteriorated under formation of numerous vesicles, large vacuoles, myelin figures, and a final rupture of the plasma membrane (Figs. 6\& 7). Losses of epithelial cells proceeded from the tips to the basal regions of the mucosal folds, until large areas of the epithelium were destroyed and the basal lamina was exposed (Fig. 8). The late merogony and early gamogony at Day 9 PE have to be considered the most pathogenic phase of the infection. In this phase, hardly any uninfected enterocytes were found. Infected epithelial tissue with highly oedematized and deformed cells accompanied devastated lamina propria areas without any epithelial cells (Figs. $7 \& 10$ ). In some cases, the basal lamina disrupted at the tips of mucosa folds, and propria material was discharged into the gut lumen (Fig. 9). In some individuals, the intestinal tissue was 


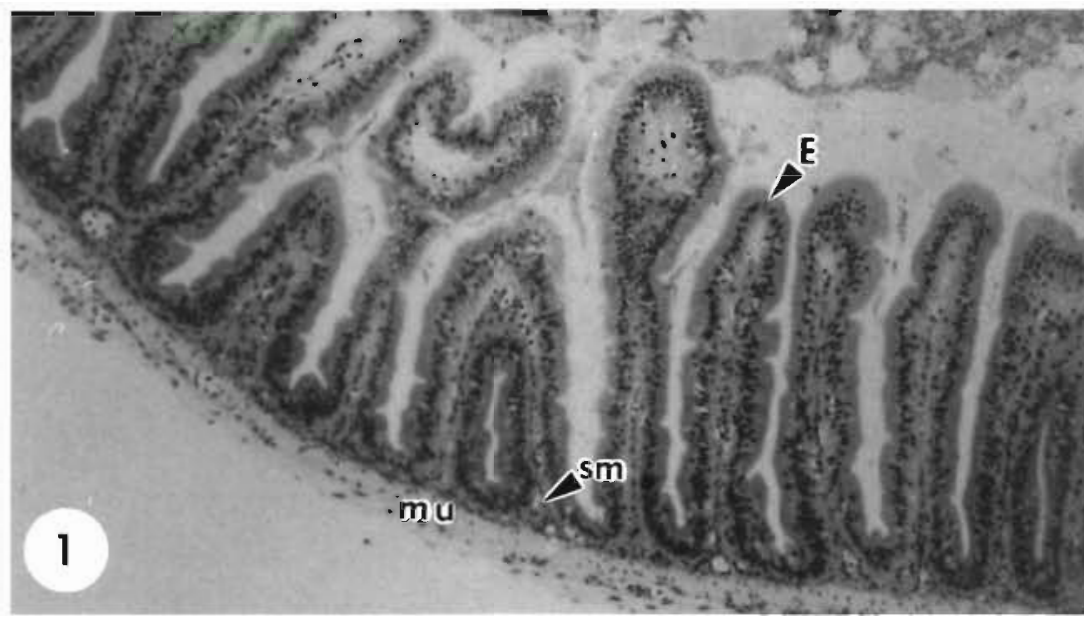

\section{3}
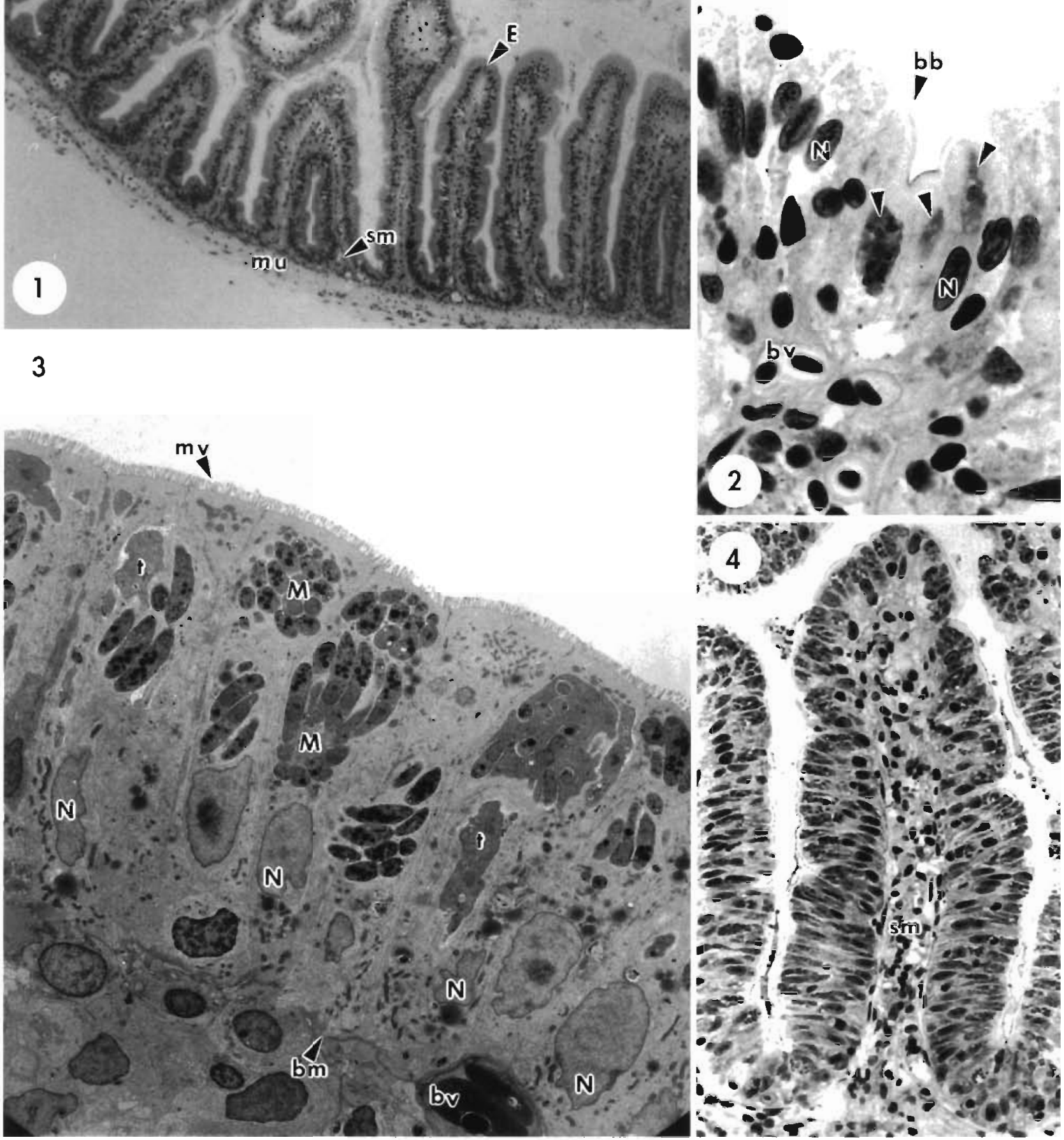

Fig. 1 Cyprinus carpio. Intestinal tissue from uninfected carp. The mucosa forms folds which extend into the gut lumen. E: epithelium; sm: submucosa; mu: muscularis. (LM, Giemsa, $\times 90)$

Figs. 2 to 4. Cyprinus carpio infected with Goussia carpelli. Fig. 2. Early trophozoites (arrowheads) within enterocytes, Day 4 PE The epithelium is not affected, the brush border (bb) forms a narrow confluent rim. $\mathrm{N}$ : nuclei of enterocytes; bv: blood vessel (LM, Giemsa, $\times 860$ ). Fig. 3. Trophonts (t) and meronts $(M)$ in apical regions of enterocytes, Days 5 to 9 PE. Number and length of microvilli (mv) are reduced. bm: basal lamina (TEM, $\times 2000$ ). Fig. 4. Days 6 to 9 . Nearly all enterocytes from the tip to the basis of the mucosal fold are infected with coccidian stages (LM, Giemsa, $\times 340$ ) 


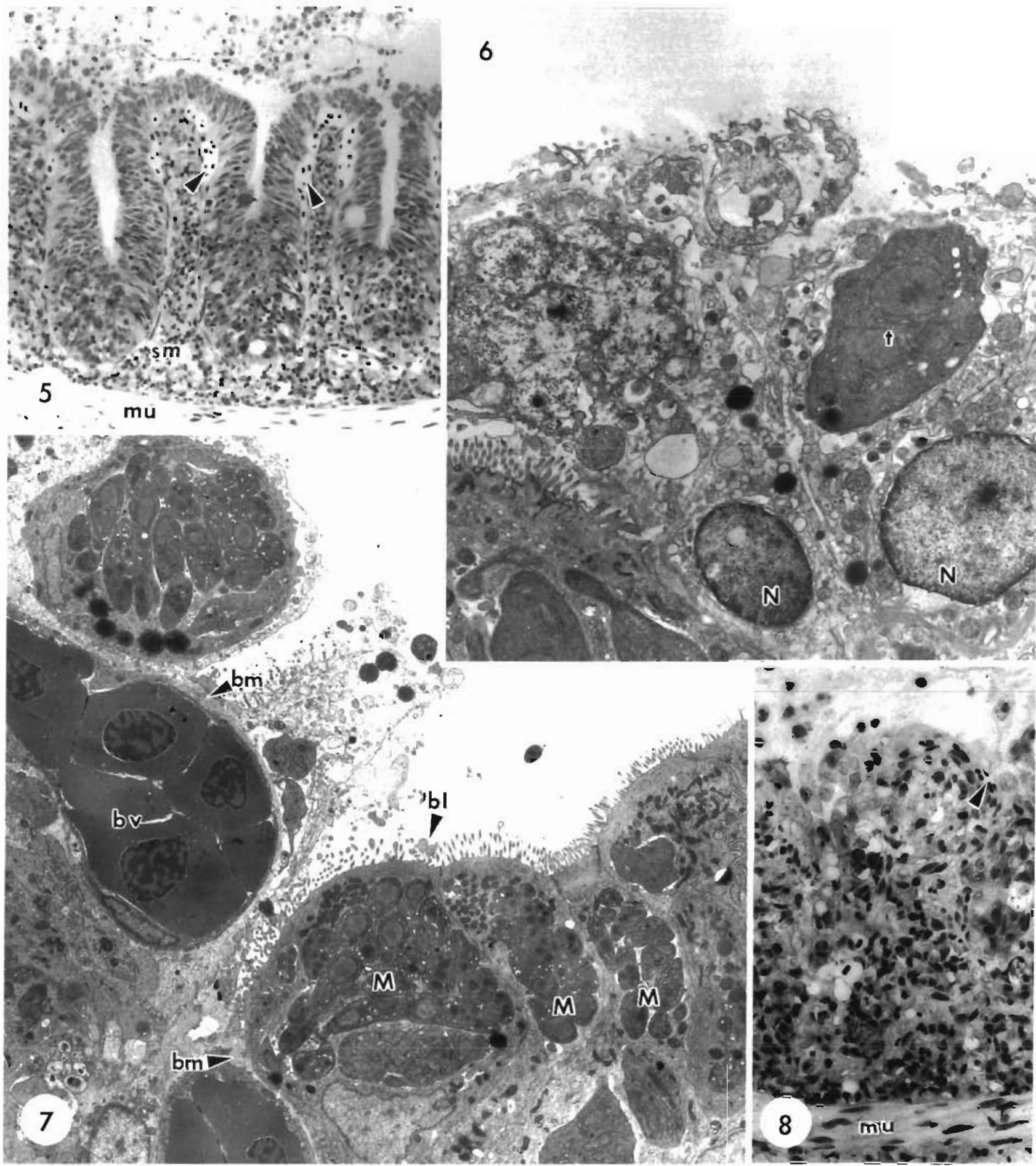

Figs. 5 to 8. Cyprinus carpio intestinal tissue infected with Goussia carpelli merogonic stages, Days 5 to 9 PE. Fig. 5 . Early local epithelium losses at the tip of mucosal folds. Beneath the basal lamina are dilated blood vessels (arrowheads). sm: submucosa; mu: muscularis (LM, Giemsa, $\times 160$ ). Fig. 6 . Necrotic enterocytes. The cell content disintegrates into numerous vesicles. The enterocyte in the lower left hand is still vital. N: nuclel of disintegrated enterocytes; t: trophozoites (TEM, $\times 6.300)$. Fig. 7. Affected epithelium with destroyed areas on the left. The basal lamina (bm) is covered by cellular debris only. A blood vessel (bv) comes to the surface. Vital, but highly infected, enterocytes are visible on the right. $M$ : meront; bl: blebs, vesicular formations of the microvilli $(T E M, \times 3000)$. Fig. 8. The epithelial cover of the submucosa is completely disrupted. A blood vessel (arrowhead) lies just beneath the surface. mu: muscularis (LM, Giemsa, $\times 340$ ) 


\section{9}

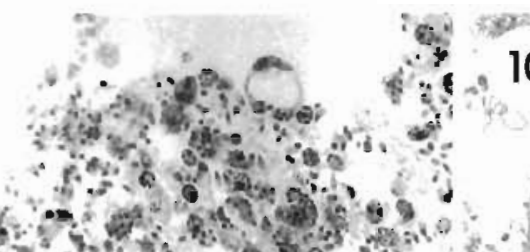

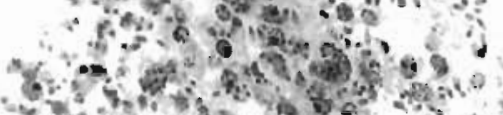

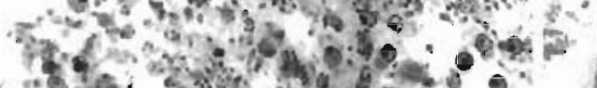

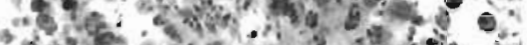
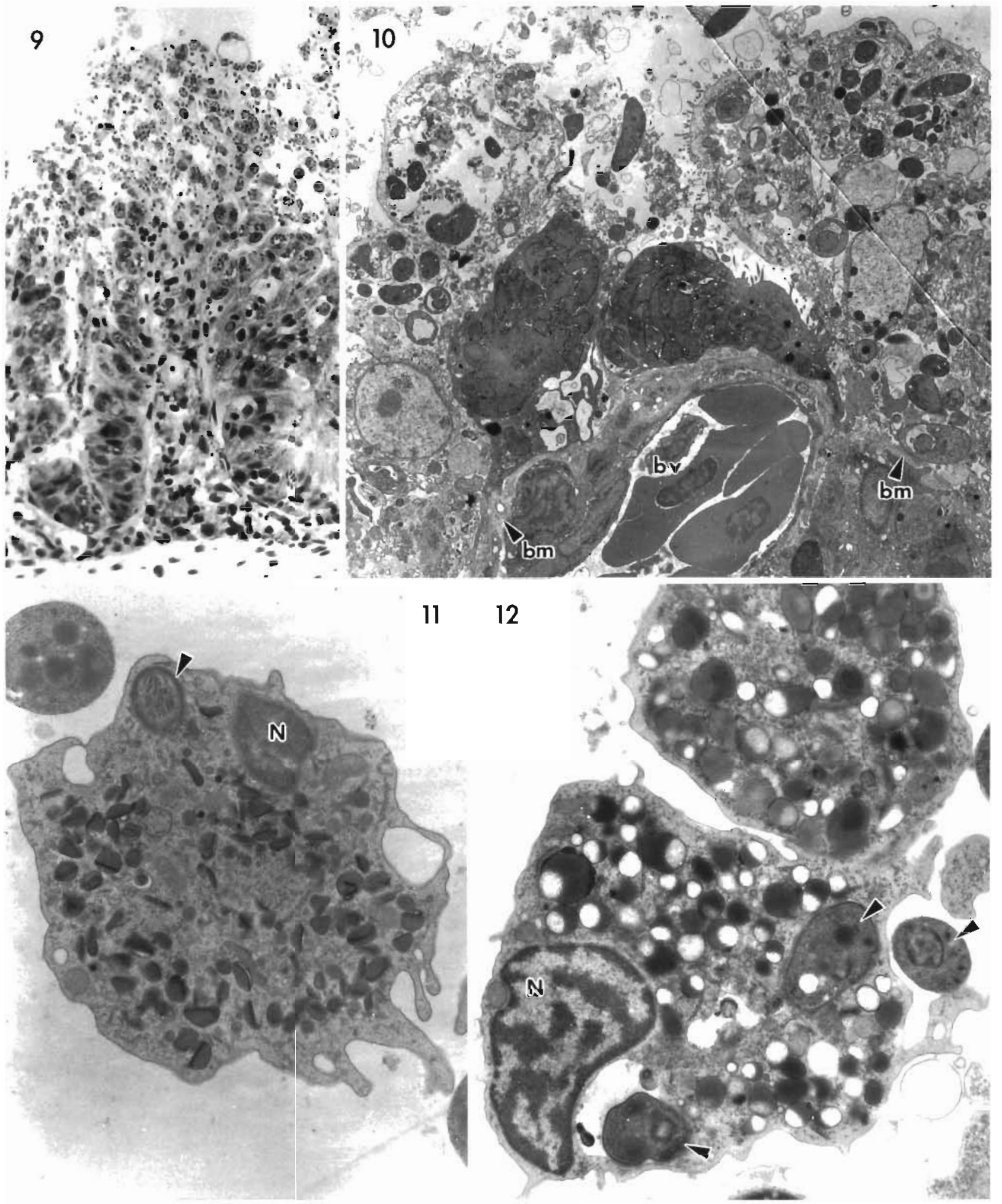

Figs. 9 to 12. Cyprinus carpio infected with Goussia carpelli, Days $9 \& 10$ PE. Fig. 9. The tip of a mucosal fold is destroyed, material from the submucosa and parasites have been released into the gut lumen. Basal enterocytes are highly parasitized but still vital (LM, Giemsa, $\times 340$ ). Fig. 10. Necrotizing enterocytes. A dilated blood vessel (bv) lies beneath the basal lamina (bm) (TEM, $\times 2700$ ). Figs. $11 \& 12$. C. Carpio phagocytic cells, Day 10 PE. Fig. 11. A heterophilic granulocyte has incorporated a merozoite (arrowhead). N: nucleus (TEM, $\times 8500$ ). Fig. 12. 'Thick-granule' granulocytes from the gut lumen. This granulocyte type also has phagocytosed merozoites (arrowheads) (TEM, ×8800) 


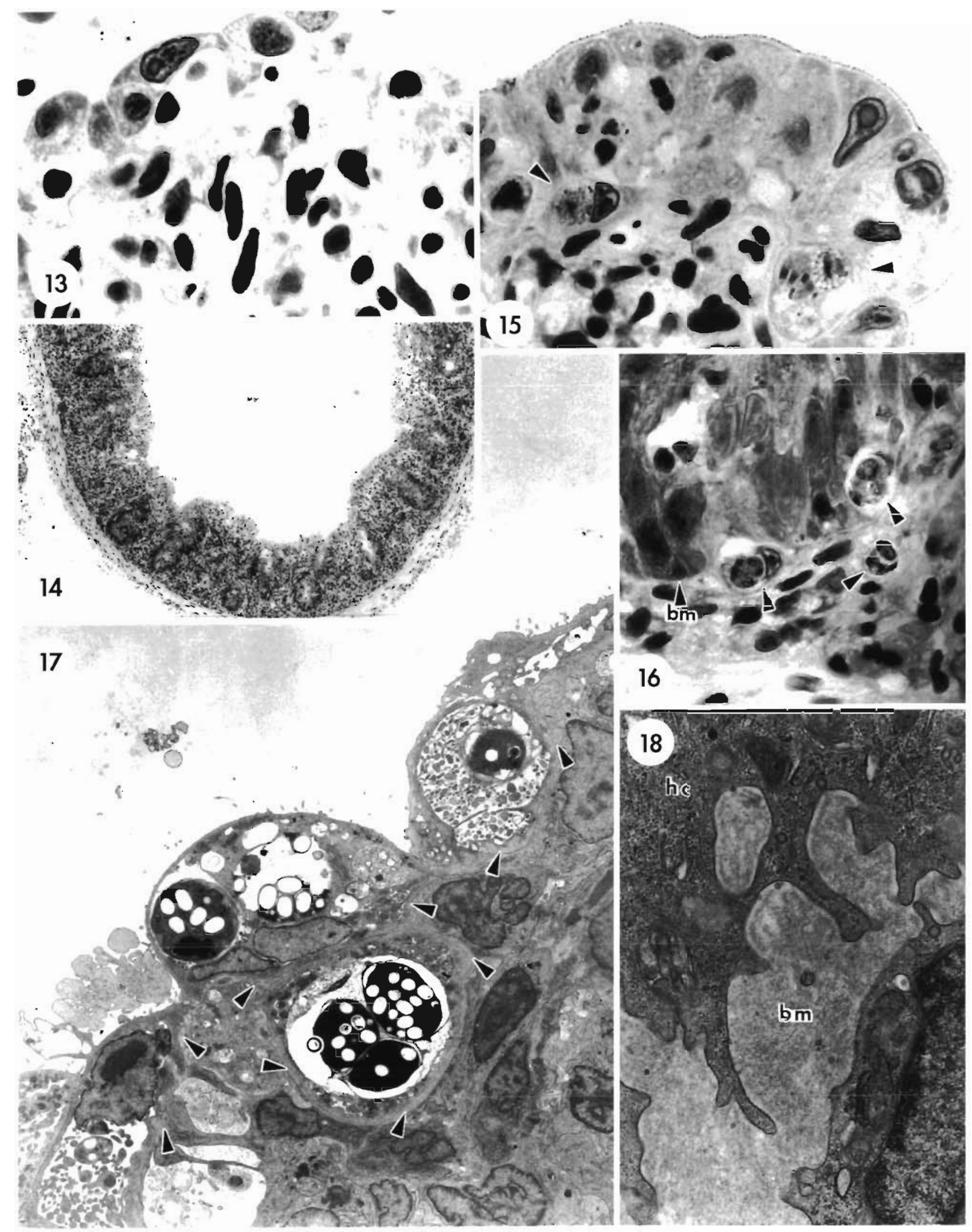


completely destroyed; it remained as a narrow fringe of submucosa and a few spots of epithelial tissue at the basis of the mucosal folds. In these carp, the intestinal lumen was filled with masses of parasites, disrupted host cells, inflammatory cells, mucus, blood and cell debris (see Fig. 25). This serious destruction of the intestinal epithelium occurred from Days 9 to $10 \mathrm{PE}$.

At this time, numerous phagocytic cells appeared in the intestinal tissue. Under the electron microscope, mononuculear cells, heterophilic granulocytes (Fig. 11) and 'thick granule (TG) leucocytes' (Fig. 12; nomenclature according to Ferrer et al. 1993) could be discerned. TG leucocytes had a disc-like nucleus and numerous membrane-bound round granules with a diameter of 600 to $800 \mathrm{~nm}$. Some of these TG leucocytes contained granules with an electron-lucent core and an electron-dense fringe. The granules of other TG leucocyte cell populations had cloudy areas of electron-dense and electron-lucent appearance (Fig. 12). Often TG leucocytes with both types of granules were found. The terms 'eosinophilic' and 'basophilic', which are widely used to describe carp granulocyte populations, are avoided here. Macrophages, heterophilic granulocytes and TG leucocytes showed high phagocytic activity both in the tissue and in the gut lumen. There was no difference between the 3 cell types with regard to phagocytic activity, efficiency and size of the particles engulfed.

At Day $11 \mathrm{PE}$, regeneration of destroyed tissue began. Broad, plain cells similar to a squamous epithelium started to cover the bare lamina propria (Fig. 13). At this time, the mucosa infoldings were almost lost. In cross sections, the intestine had the appearance of a tube with a uniform wall (Figs. $14 \& 26$ ). During the further process of regeneration, smooth, broad mucosa folds were formed (Fig. 27). The cells which covered the lamina propria were initially squamous, developed subsequently a cubic outline, but did not show the polarity chacteristic for enterocytes (Fig. 15). These cells had only few microvilli, an irregular nucleus and long fingerlike protrusions which formed close cell contacts. The squamous cells were already found to be infected by parasite stages (Figs. $15 \& 17$ ).
The phase of gamogony and oocyst formation (Days 11 to $14 \mathrm{PE}$ ) was characterized by processes of regeneration. Heavily infected enterocytes, however, deteriorated and caused small local epithelial losses (Figs. 17 \& 19).

Enterocytes with developing oocysts underwent various processes. Heavily infested enterocytes containing more than 2 oocysts died and released the oocysts into the gut lumen before sporulation was completed (Fig. 17). Other cells remained in the epithelium and died during the normal cell turnover, while harbouring a fully sporulated oocyst. Some enterocytes containing not more than 2 developing oocysts seemed to perform a peculiar migratory process: they became spherical, lost contact to the luminal surface and thus seemed to leave the epithelial lining towards more basal layers. Finally, these cells were found adjacent to the basal lamina (Figs. 15, $16 \& 20$ ), and above these cells, the epithelium had closed again. Oocyst-bearing cells often were found to penetrate the basal lamina and lay in submucosal tissue (Fig. 16). Electron microscopical observations of this process showed that these enterocytes initially formed a protrusion of the basal lamina which was much thinner in this area (Fig. 17). The host cells often sent root-like extensions into the basal membrane (Fig. 18), which were not visible in uninfected enterocytes. The entire passage of the basal lamina, however, could not be observed. A participation of phagocytes in this process was not seen.

At about 15 d PE merogonic and gamogonic development of Goussia carpelli ended and regeneration of tissue damage was complete. Epithelial cells with a cubic outline differentiated to characteristic tall cylindrical enterocytes. The epithelial lining was uniform, confluent, and a homogeneous nucleus level was discerned. Furthermore, the mucosa folds were re-established (Fig. 19). The cell infiltration of the submucosa decreased slowly, while the cell density was at a higher than normal level up to the end of the observation period. Sporoblasts and sporulated oocysts of $G$. carpelli lay solitarily in unaffected tissue (Fig. 20). During further development, aggregations of oocysts and eosinophilic granular material ('yellow bodies') were

Figs. 13 to 18. Cyprinus carpio infected with Goussia carpelli. Fig. 13. Repair of destroyed epithelium, Day 11 PE. Squamous to cubic epithelium cells with no polarity cover the submucosa (LM, Giemsa, $\times 780$ ). Fig. 14. Cross-section of a heavily infected intestine, Day $11 \mathrm{PE}$. The mucosa relief has been lost. Some remnants of epithelial tissue remain in basal regions (LM, Giemsa, $\times 90$.) Figs. 15 to 18. Migration of oocyst-bearing enterocytes (Days 12 to $14 \mathrm{PE}$ ). Fig. 15. Oocyst-bearing enterocytes (arrowheads) have lost contact with the luminal surface while migrating to basal regions ( $\bar{M}$, Giemsa, $\times 860$ ). Fig. 16. Migrating oocysts (arrowheads) penetrating the basal lamina (bm) at the basis of mucosal folds (LM, Giemsa, $\times 860$ ). Fig. 17. Squamous, highly parasitized epithelial cell. An enterocyte bearing a sporulating oocyst (O) pushed the basal lamina while migrating to basal regions. The course of the basal lamina is marked by arrowheads (TEM, $\times 2800$ ). Fig. 18. Root-like extensions of a migrating host cell (hc) protrude into the basal lamina (bm) (TEM, $\times 18000)$ 


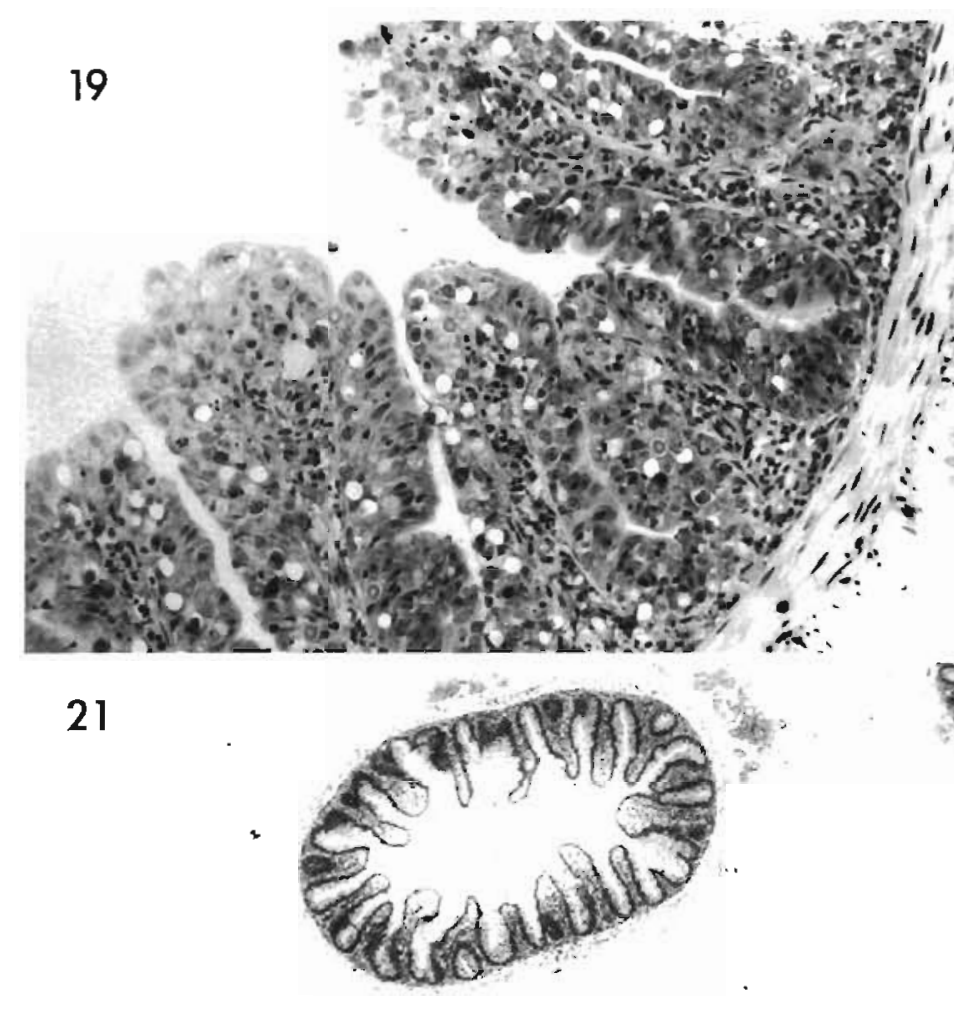

\section{0}

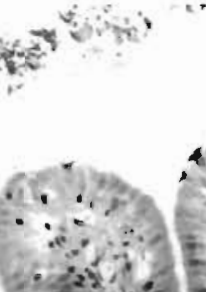
\%.
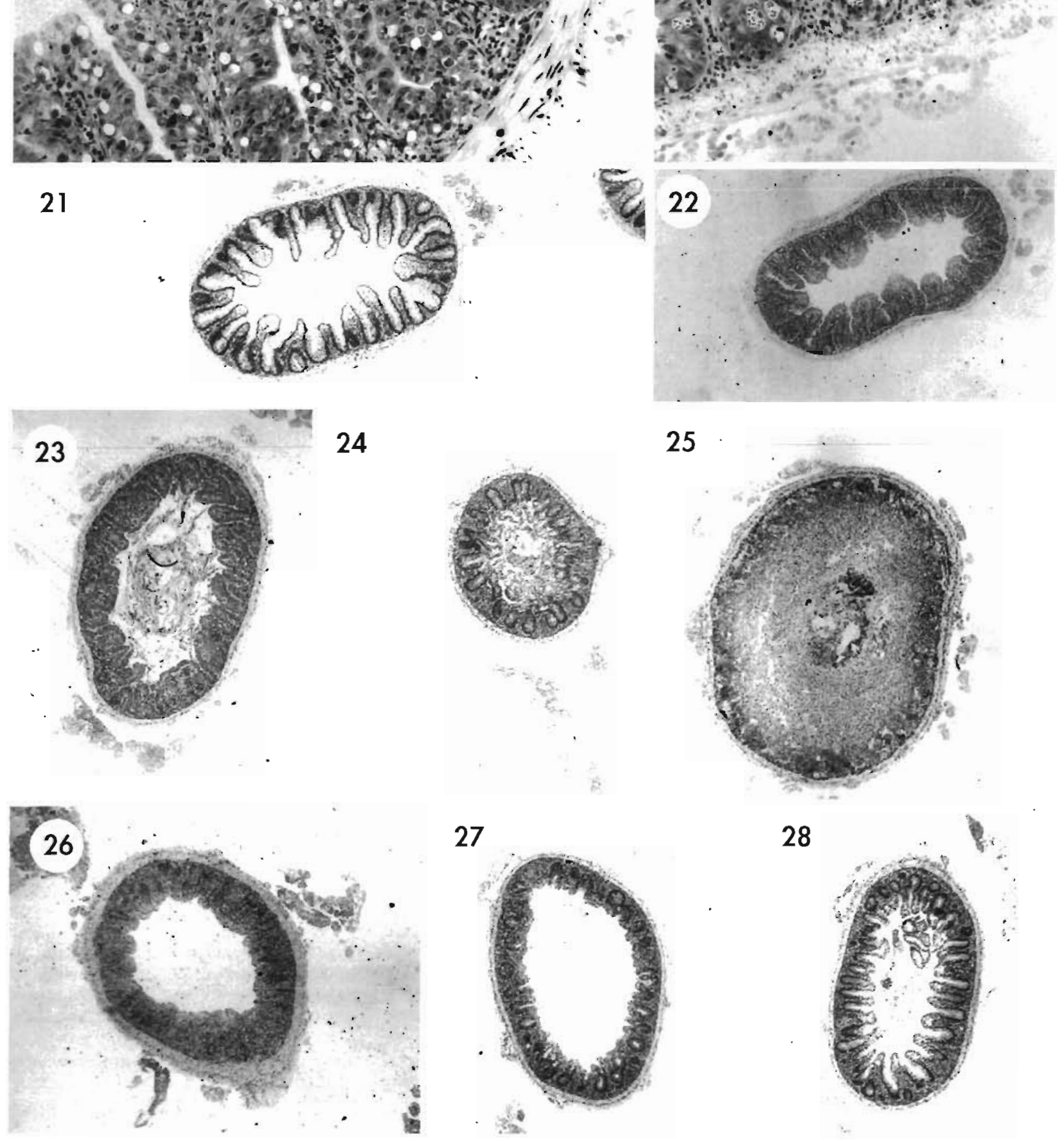
Table 1. Goussia carpelli coccidiosis in carp Cyprinus carpio. Typical morphological alterations during the course of infection

\begin{tabular}{|c|c|c|c|c|c|c|c|c|c|c|c|c|c|c|c|}
\hline Days post exposure: & 4 & 5 & 6 & 7 & 8 & 9 & 10 & 11 & 12 & 13 & 14 & 15 & 16 & 17 & 18 \\
\hline \multicolumn{16}{|l|}{ Developmental stages } \\
\hline Meronts & $\mathrm{x}$ & $\mathrm{x}$ & $\mathrm{x}$ & $\mathrm{x}$ & $x$ & $x$ & $x$ & $\mathrm{x}$ & $\mathrm{x}$ & $x$ & $x$ & & & & \\
\hline Gamonts & & & & & & $x$ & $x$ & $\mathrm{x}$ & $\mathrm{X}$ & $\mathrm{x}$ & $x$ & $\mathrm{x}$ & & & \\
\hline Oocysts & & & & & & & & & $\mathrm{x}$ & $\mathrm{x}$ & $x$ & $x$ & $x$ & $x$ & $\mathrm{x}$ \\
\hline \multicolumn{16}{|l|}{ Pathology } \\
\hline Edema & & & $x$ & $x$ & $x$ & $x$ & $\mathrm{x}$ & $\mathrm{x}$ & $\mathrm{x}$ & & & & & & \\
\hline Dislocation of organelles & & & & $x$ & $x$ & $x$ & $x$ & $\mathrm{x}$ & $\mathrm{x}$ & & & & & & \\
\hline Microvilli loss & & & $x$ & $x$ & $x$ & $x$ & $\mathrm{x}$ & $\mathrm{x}$ & $x$ & & & & & & \\
\hline Membrane blebs & & & & $x$ & $x$ & $x$ & $\mathrm{x}$ & $\mathrm{x}$ & & & & & & & \\
\hline Cell degeneration & & & & $x$ & $x$ & $x$ & $x$ & $\mathrm{X}$ & $\mathrm{x}$ & & & & & & \\
\hline Epithelium loss & & & & & $\mathrm{x}$ & $x$ & $x$ & $x$ & $x$ & & & & & & \\
\hline Destruction of mucosa folds, hemorrhage & & & & & & $x$ & $\mathrm{x}$ & & & & & & & & \\
\hline Cellular infiltration, phagocytes & & & & & & & $x$ & $\mathrm{x}$ & $\mathrm{x}$ & $\mathrm{x}$ & $x$ & $x$ & $x$ & $x$ & $\mathrm{x}$ \\
\hline Squamous epithelium & & & & & & & $x$ & $\mathrm{x}$ & $\mathrm{x}$ & & & & & & \\
\hline Regeneration of mucosa & & & & & & & & & $x$ & $\mathrm{x}$ & $x$ & $\mathrm{x}$ & $x$ & $\mathrm{x}$ & \\
\hline
\end{tabular}

formed in the epithelium and in the submucosa. The number of oocysts in the tissue decreased rapidly. About $19 \mathrm{~d}$ PE, the intestinal tissue was completely regenerated (Figs. 21 to 28). Beginning with Day 22 $P E$, some samples did not show any coccidia or histopathological changes.

A summary of typical morphological alterations during the course of a Goussia carpelli infection is given in Table 1. During the entire observation period, no clinical symptoms of coccidiosis, e.g. signs of pain, weakness or apathy, were observed in infected carp. Even though the fish showed signs of emaciation at the end of the experiments, their general appearance seemed to be unaffected.

\section{DISCUSSION}

The basic question of this study was the pathogenic potential of Goussia carpelli and its effect on the breeding success of a carp hatchery. As the information on the pathogenicity of fish coccidia is scarce, comparisons to well-examined coccidian species in mammals and birds have to be made for evaluation of the tissue changes found in $G$. carpelli infected carp.

As with most parasitic infections, Goussia carpelli does not cause disease a priori but adds to other disease factors. In the natural environment, coccidia pass the intestines of their hosts without provoking any clinical symptoms. Crowded housing of domestic animals results in an accumulation of infective oocysts in the surroundings, which then provokes heavy infections and severe disease (Long 1973). Even though carp hatcheries in Germany are often managed in an extensive or semi-extensive manner, the accumulation of numerous fish in a confined area is sufficient to provoke a clinically manifest coccidiosis caused by a parasite well adapted to its host and of minor pathogenic potential. Gut-dwelling coccidia are usually considered to be less pathogenic than species which are par-

Figs. 19 to 28. Cyprinus carpio infected with Goussia carpelli. Figs. 19 \& 20. Repair of damaged epithelium, Days 13 to 15 PE. Fig. 19. The mucosa is re-established. The tissue bears numerous oocysts. These often came off during the preparation of the slides and are thus visible as holes. The submucosa again has its original cell density (LM, Giemsa, $\times 180$ ). Fig. 20. Oocysts are lying in tissue which shows no alterations $(\mathrm{LM}$, Giemsa, $\times 180)$. Figs. 21 to 28 . Cross-sections of intestine, showing the effect of infection. Fig. 21. Uninfected control carp. Narrow, tall, occasionally merged mucosal folds protrude into the gut lumen. In the epithelium a nucleus zone is clearly visible. Fig. 22. Day 6 PE. A swelling of mucosa folds is evident; a nucleus region can no longer can be detected. The epithelium, however, is still confluent. Fig. 23. Day 7 PE. In the submucosa, some dilated blood vessels are visible. First epithelium losses appear. Fig. 24. Day 8 PE. At the tips of mucosa folds major epithelium damage occurs. Host cells and parasites lie in the gut lumen. Fig. 25. Day 9 PE. Severe necrotizing enteritis. The weak intestine is dilated and filled with detritus, fibrine and parasites. Fig. $2 \overline{6 \text {. Day } 11} \mathrm{PE}$. The mucosa relief is almost completely destroyed, the folds are fused. The submucosal connective tissue shows a cell infiltration. Fig. 27. Day $13 \mathrm{PE}$. New mucosa folds are formed. The epithelium starts to regenerate a regular structure with a nucleus zone. Fig. 28. Day $15 \mathrm{PE}$. The mucosa is almost repaired. The folds have reached their original height, but a cell infiltration is still visible in propria and submucosa. (All figures LM, Giemsa, $\times 20$ ) 
asitic in other tissues (Long 1973, 1982). Among gutinfecting coccidia, small species located in epinuclear areas of the host cell are regarded as largely nonpathogenic, because they hardly affect the physiological processes of the enterocyte, e.g. Eimeria praecox from chicken (Long 1967) and Epieimeria isabellae from anguilliform fishes (Daoudi et al. 1986). In the present study early stages of Goussia carpelli, which occupied only the epinuclear cytoplasm of infected enterocytes, also did not induce any obvious pathological changes. With the increase of the parasites in number and size, extensive necrosis of infected enterocytes occurred. In the electron microscope, infected enterocytes showed all stages of cell death as described by Dahme \& Schröder (1982). These signs of deterioration of enterocytes are not specific, i.e. enterocytes react similar to a wide variety of different agents. In accordance with Long's (1973) observations on coccidia of warmblooded vertebrates, the most pathogenic phase of the G. carpelli infection, with the highest number of parasites present, was reached during late merogony and early gamogony (Days 9 and $10 \mathrm{PE}$ ).

The impact of intestinal epithelium losses on the physiology of homoiothermic vertebrates is discussed by Preston-Mafhan \& Sykes (1967) and Long (1973, 1990): the absorption of nutrients is disturbed, and an increased permeability of the intestinal wall leads to liquid, salt and protein leakages into the gut lumen. An invasion of bacteria, viruses, fungi or toxins is no longer hindered by the epithelial barrier. For freshwater fishes, the aspect of liquid loss might not be as serious as it is for terrestrial animals. Diarrhoea, a major pathogenic component in mammalian and avian coccidiosis, is of minor importance for freshwater fishes, which live in a hypotonic aquatic medium and have to excrete water constantly.

Our observations have further revealed that in affected intestinal segments Goussia carpelli infected all enterocytes of mucosa folds from the tip to the basis. In mammalian and avian hosts, coccidia infecting mature enterocytes towards the tip of the villi are regarded to be less pathogenic, because regeneration of the epithelium originates from stem cells in the crypts and is not disturbed by these parasites (Long 1990). This is the case in Eimeria averculina in chicken, E. bakuensis in sheep, primarily lamb, and Isospora suis in swine (Long 1990). Other species have greater pathogenic effects by damaging the stem cells in the crypts, e.g. E. ovinoidalis in lamb (Gregory \& Catchpole 1987) and E. flavescens in rabbit (Gregory \& Catchpole 1986). This causes significant delays in epithelium regeneration and an extension of the problems mentioned above. On the basis of its pathogenic effects, $G$. carpelli has to be ranked between these 2 examples. G. carpelli infects enterocytes at the base of the mucosa folds, but the damage to these cells is not as great as at the tips of the folds. This can be compared to Eimeria bakuensis (Gregory \& Catchpole 1987 ) and E. crandallis (Long 1990) which also infect stem cells without damaging them.

A further important indicator of pathogenicity in coccidiosis is the depth of the lesions in the tissue. At the peak of the Goussia carpelli infection at Day 9 PE, tissue damage was observed in the epithelium and in the lamina propria as well, and lamina propria material was released into the gut lumen. Homoiothermic animals with comparable lesions often suffer from enterorrhagia and a serious disturbance of their general condition (e.g. Eimeria zuernii and E. bovis in cattle: Levine \& Ivens 1970, Niilo 1970; E. ovinoidalis and E. ninakohlyakimovae in sheep, E. meleagrimitis in turkey and E. irresidua in rabbit: Long 1973). Surprisingly, infected carp did not show any clinical symptoms. The intestine was neither hyperaemic nor filled with bloodish contents, but was pale, limp, and filled with mucous matter. Compared to birds and mammals, carp showed a mild reaction to the severe tissue damage caused by the coccidia. This might be explained by a low tendency of fishes to develop acute inflammatory reactions, even though teleost fishes possess all the cells and physiological pathways required for these reactions (Ferguson 1989). It was assumed (Ferguson 1989) that this might be explained by retarded biochemical reactions due to the poikilothermic physiology of fishes. Unlike terrestrial animals, aquatic organisms have no neccessity to dilute harmful agents by extensive exudate formation. An overshooting acutephase host defence often causes severe tissue damage (Long 1990). As carp did not develop an acute inflammatory response, further serious tissue damage might be prevented.

Epithelial losses in the small intestine of birds and mammals caused by different agents always resulted in villi atrophy (Brandborg 1971, Fernando \& Mc Craw 1973, Long 1990). This process, which represents the host's efforts to minimize the unprotected intestinal surface, was also observed in the carp intestine. The mucosa folds were lost but were restored by Day $20 \mathrm{PE}$ (Figs. 21 to 28).

The dislocation process of oocyst-bearing enterocytes towards the submucosa needs to be studied in more detail. In contrast to descriptions of previous authors, in this study the dislocation appeared to be an active process of the host cell. While Plehn (1924) described a migration as an action directed by the parasite, Schäperclaus (1943) and Molnár (1981) argued that the affected host cells degenerated and were displaced to deeper tissue regions by intact cells. In the present study, dislocated host cells were still active. As could be seen in the electron microscope, these cells 
were transformed both morphologically (loss of the microvillar lining, globular surface line of the cell) and functionally in the sense of a dedifferentiation. The highly specialized enterocytes seemed to develop towards a motile cell, which appeared to leave its original tissue and to invade a foreign tissue. It could not be observed that 'migrating' oocyst-bearing enterocytes degenerated (as shown by Benajiba et al. 1994 in Eimeria anguillae) or were engulfed by leucocytes (e.g. granulocytes or macrophages). Fernando et al. (1983) observed a similar process in the intestine of chicken infected with Eimeria necatrix and E. tenella. In this case, first generation meronts caused their host cells to migrate through the basal lamina into the submucosa. Pasternak \& Fernando (1984) demonstrated the production of a collagenase by the infected cell. Similar studies on enterocytes from Goussia carpelli infected carp are lacking.

The observations on the phagocytic activity of carp granulocytes also differ from those previously reported: Hine (1992), Secombes \& Fletcher (1992) and Temmink \& Bayne (1987), who applied an in vitro phagocytic assay, state that 'eosinophilic' and 'basophilic' granulocytes are effectors of extracellular defence and have no phagocytic capacity. Granulocytes observed in the present study, however, showed high phagocytic activity similar to that of macrophages and heterophilic granulocytes. The contrasting points of view concerning the phagocytic activity of different types of granulocytes may be caused by a different reaction of these cells in vivo and in vitro. Here also further studies are required for clarification. The terms 'eosinophilic' and 'basophilic' granulocytes, which are commonly used in the literature to classify carp granulocytes, cannot be accepted without discussion. These terms were chosen according to the nomenclature of mammalian granulocytes and with regard to ultrastructural characteristics but less on the basis of functional or histochemical assays. Many authors, while studying granulocytes of carp, also assume that cells named 'eosinophils' and 'basophils' might resemble cells of a common lineage (Cenini 1984, Temmink \& Bayne 1987, Rowley \& Ratcliffe 1988, Hine 1992). Therefore, it appears more useful to accept the descriptive term 'thick-granule leucocytes' coined by Ferrer et al. (1993).

In this laboratory infection experiment, Goussia carpelli proved to be a coccidian species with high pathogenic capacities. Whether the results of the infection experiment can be transferred to field conditions is a matter for debate. Carp used in the experiment were raised in a coccidia-free environment. At the start of the experiment, the immunological status of carp used corresponded to the status of carp fry from the ponds, which acquire the infection with the start of feeding. In the experiment, the doses of infective oocysts could not be determined exactly. Infection of carp with Goussia carpelli via a pharyngial tube was not possible due to a reflex closing of the pharyngial teeth as soon as the tube was introduced orally. Therefore, the carp were placed into an infection tank contaminated with $G$. carpelli oocysts from a previous infection of carp. It can be assumed that the infection pressure in the contaminated tank might be comparable to conditions in a carp pond.

The course of infection by Goussia carpelli, which depends on the water temperature, according to Steinhagen et al. (1989), has a high impact on the pathogenicity. The infection experiment was performed at a water temperature of 20 to $22^{\circ} \mathrm{C}$. Young carp in the pond acquired an infection at a time when the water has a temperature of 17 to $18^{\circ} \mathrm{C}$. The more delayed development of the coccidia at this temperature certainly decreases the pathogenicity because not as many enterocytes are destroyed at the same time as in a more rapid development. However, it should be taken into consideration that host defence reactions and tissue regeneration is also slowed down at lower temperatures (Rijkers et al. 1980).

Interactions with other pathogens, which occur in the pond at the same time together with Goussia carpelli, have to be emphasized. Young carp face a large number of different stressors such as ecto- and endoparasites, and fungal, bacterial and viral infections. Further impairments occur with food shortage, temperature variation and stress caused by predators or husbandry. Under these conditions, their resistance to a coccidian infection will be markedly decreased (Long 1990).

\section{LITERATURE CITED}

Alvarez-Pellitero, M. P., Gonzalez-Lanza, M. C. (1985). Goussia carpelli (Protozoa, Apicomplexa) in cyprinid fish of the Dureo Basin (NW Spain). Aspects of host-parasite relationships. J. appl. Ichthyol. 3: 125-130

Amlacher, E. (1981). Taschenbuch der Fischkrankheiten, 4th edn. Fischer Verlag, Stuttgart

Benajiba, M. H., Marques, A., Lom, J., Bouix, G. (1994), Ultrastructure and sporogony of Eimeria (syn. Epieimeria) anguillae (Apicomplexa) in eel (Anguilla anguilla). J. eukaryot. Microbiol. 41: 215-222

Brandborg, L. L. (1971). Structure and function of the small intestine in some parasititc diseases. A.m. J. clin. Nutr. 24: $124-132$

Cenini, P. (1984). The ultrastructure of leucocytes in carp (Cyprinus carpio). J. Zool. 204: 509-520

Dahme, E., Schröder, B. (1982). Allgemeine Stoffwechselstörungen. In: Kitt, T., Schulz, L. C. (eds.) Lehrbuch der allgemeinen Pathologie für Tierärzte und Studierende der Tiermedizin, 9th edn. Enke Verlag, Stuttgart, p. 131-196

Daoudi, F., Blanc, E., Marques, A., Bouix, G. (1986). L'action histopathologique de quelques coccidies de poissons méditerranéens (Golfe du Lion). Pathologie en aquaculture marine. European Aquaculture Society, Special Pub- 
lication No. 9, Bredene, p. 111-115

Doflein, F., Reichenow. E. (1953). Lehrbuch der Protozoenkunde, 6 th edn. Fischer Verlag, Stuttgart

Ferguson, H. W. (1989). Systemic pathology of fish. Iowa State University Press, Ames

Fernando, M. A., Lawn, A. M., Rose, M. E., Al-Attar, M. A (1983). Invasion of chicken caecal and intestinal lamina propria by crypt epithelial cells infected with coccidia. Parasitology 86: 391-398

Fernando, M. A., Mc Craw, B. M. (1973). Mucosal morphology and cellular renewal in the intestine of chickens following a single infection of Eimeria averculina. J. Parasitol 59 493-501

Ferrer, M., Alcober, V., Trigoso, I., Tato, A., Stockert, J. C. (1993). Cytological observations on blood granulocytes of the carp (Cyprinus carpio L.) with special reference to the structure of layered inclusions within specific granules. Zool. Jb. Anat. 123: 75-83

Gregory, M. W., Catchpole, J. (1986). Coccidiosis in rabbits the pathology of Eimeria flavescens infection. Int. J. Parasitol. 16: 131-145

Gregory, M. W., Catchpole, J. (1987). Ovine coccidiosis pathology of Eimeria ovinoidales infection. Int. J. Parasitol. 17: 1099-1111

Hine, P. M. (1992). The granulocytes of fish. Fish Shellfish Immunol. 2: $79-98$

Kent, M. L., Hedrick, R. P. (1985). The biology and associated pathology of Goussia carpelli in goldfish Carassius auratus (Linnaeus). Fish Pathol. 20: 485-494

Kocylowski, B., Zelazny, J., Antychowitz, J., Pancyk, J. (1976). Incidence of carp coccidiosis and its control. Bull. vet. Inst Pulawy 20: 12-17

Léger, L., Stankovitch (1921). L'entérite coccidienne des alevins de carpe. Trav. Lab. Piscicult. Université Grenoble 13: $339-342$

Levine, N. D., Ivens, V. (1970). The coccidian parasites (Protozoa, Sporozoa) of ruminants. Illinois Biological Monographs 44, Univ. of lllinois Press, Urbana

Lom, J., Dyková, I. (1992). Protozoan parasites of fishes Developments in Aquaculture and Fisheries Sciences 26. Elsevier, Amsterdam

Long, P. L. (1967). Studies on Eimeria praecox, Johnson, 1930, in the chicken. Parasitology 57: 341-361

Long, P. L. (1973). Pathology and pathogenicity of coccidial infections. In: Hammond, D. M., Long, P. L. (eds.) The coccidia. University Park Press, Baltimore, p. 253-294

Long, P. L. (1982). The biology of the coccldia. University Park Press, Baltimore

Long, P. L. (1990). Coccidiosis of man and domestic animals. CRC Press, Boca Raton

Molnár, K. (1981). Some peculiarities of oocyst rejection of fish coccidia. In: Fish, pathogens and environment in European polyculture (Proceedings of an International Symposium, 23-27 June, 1981). Fisheries Research Institute, Szarvas, p. $170-183$

Niilo, L. (1970). Bovine coccidiosis in Canada. Can. Vet. J. 11. 91-98

Pasternak, J., Fernando, M. A. (1984). Host cell response to coccidian infection: an introspective survey. Parasitology 88: $555-563$

Plehn, M. (1924). Praktikum der Fischkrankheiten. Schweizerbartsche Verlagsbuchhandlung, Stuttgart

Preston-Mafhan, R. A., Sykes, A. H. (1967). Changes in the permeability of the mucosa during intestinal coccidiosis infections in fowl. Experientia 23/11: 972-973

Reichenbach-Klinke, H. H. (1980). Krankheiten und Schädigungen der Fische, 2nd edn. Fischer, Stuttgart

Rijkers, G. T., Frederik-Wolters, E. M. H., van Muiswinkel, W. B. (1980). The immune system of cyprinid fish. Kinetics and temperature dependence of antibody producing cells in carp (Cyprinus carpio). Immunology 41.91-97

Rowley, A. F., Ratcliffe, N. A. (1988). Vertebrate blood cells. Cambridge University Press, Cambridge

Schäperclaus, W. (1943). Die Darmcoccidien, insbesondere die Knötchencoccidiose des Karpfens. Z. Fisch. 41: 283-295

Schäperclaus, W. (1979). Fischkrankheiten, 4th edn. Akademie Verlag, Berlin

Secombes, C. J., Fletcher, T. C. (1992). The role of phagocytes in the protective mechanisms of fish. A. Rev. Fish Dis. 2: $53-71$

Steinhagen, D., Körting, W., van Muiswinkel, W. B. (1989). Morphology and biology of Goussia carpelli (Protozoa: Apicomplexa) from experimentally infected common carp Cyprinus carpio. Dis. aquat. Org. 6: 93-98

Temmink, H. J. M., Bayne, C. J. (1987). Ultrastructural characterisation of leucocytes in the pronephros of carp (Cyprinus carpio L. ). Dev. comp. Immunol. 11: 125-137

Manuscript first received: March 18, 1994

Revised version accepted: September 28, 1994 